\title{
Evaluation of the Levels and Quality of Microbial Contamination in Medical Emergency Departments in Comparison to Other Workplaces
}

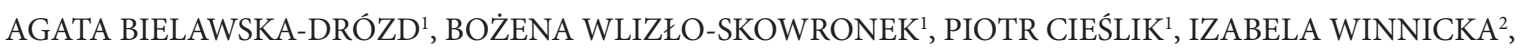 \\ EWA SKOPIŃSKA-RÓŻEWSKA ${ }^{3,2}$, LESZEK KUBIAK², DOROTA ŻAKOWSKA ${ }^{1}$, \\ ALEKSANDRA BREWCZYŃSKA ${ }^{2}$ and JANUSZ KOCIK ${ }^{2}$ \\ ${ }^{1}$ Biological Threats Identification and Countermeasure Centre, \\ Military Institute of Hygiene and Epidemiology, Warsaw, Poland \\ ${ }^{2}$ Laboratory of Epidemiology, Military Institute of Hygiene and Epidemiology, Warsaw, Poland \\ ${ }^{3}$ Pathology Department, Biostructure Centre, Medical University of Warsaw, Poland
}

Submitted 2 December 2015, revised 12 January 2016, accepted 1 February 2016

\begin{abstract}
Work in Hospital Emergency Departments (HEDs) exposes both the emergency ward staff and patients to infectious and in other way harmful biological agents. The results of this study shows the presence of pathogenic bacteria isolated by three different methods. It revealed $9.8 \%$ of pathogens detected by imprint method, $10.5 \%$ of pathogens by swabbing method, $17.6 \%$ and $22 \%$ in HEDs corridors and rooms, respectively, by air sampling method. In control workplaces (offices) pathogenic bacteria reached the level of $6.5 \%$ and $14.7 \%$ by imprint method and swabbing, respectively. The relatively low level of contamination by bacteria in HEDs may depend on the effectiveness of Standard Protective Precautions in the studied hospitals.
\end{abstract}

Ke y words: harmful biological agents, Hospital Emergency Department, antimicrobial resistance, microbiological monitoring surface and air samples

In accordance with the Act of 8 September 2006 on State Emergency Medical Services, the Hospital Emergency Department (HEDs) is a hospital ward whose main task is to provide comprehensive health services to adults and children in cases of sudden or life-threatening injuries or illnesses (isap.sejm.gov.pl) (ISAP, 2011). HEDs activities are focused mainly on stabilizing the patients, providing an initial diagnosis and transporting the patients to specialised wards for further treatment.

The character of HEDs work exposes both the emergency ward staff and patients to the presence of dangerous biological agents; however, the level of microbiological risk is not only related to the specifics of HEDs' functioning but it is also to the manner of performing the medical procedures by healthcare professionals. Followed correctly and in accordance with sanitation standards, medical procedures ensure security for both patients and medical personnel at the initial stage of treatment. The level of microbiological safety is further enhanced by ensuring that hospital environment is free of microorganisms capable of causing infection.
Pathogenic microorganisms in hospital environments such as HEDs are located generally on the surfaces of medical devices, as well as on the surfaces in direct contact with patients (walls, bed frames, medical devices switches, sinks etc.) and may pose the risk of hospital acquired infections (HAIs). The most common routes of transmission of potential pathogens are: direct contact with infected hospital personnel and contact between patients (cross transmission). Inaccurate cleaning of rooms or incorrect disinfection of medical equipment contributes to the spreading of pathogens through the devices routinely used in diagnosis, treatment and rehabilitation (Fiedotow and Denys, 2006). Bacteriological monitoring of hospital environment enables detection and differentiation of the colonizing and infective bacterial flora and provides the basis for effective empiric antibiotic therapy and eradication of the microorganisms from the ward environment (Maszkiewicz, 2007).

Systematic surveillance of infections, mainly by identifying the etiological agents of HAIs, enables identification of the most commonly found microorganism,

\footnotetext{
* Corresponding author: A. Bielawska-Drózd, Biological Threats Identification and Countermeasure Centre, Military Institute of Hygiene and Epidemiology, Warsaw, Poland; e-mail: abielawska@wihe.pulawy.pl
} 
posing a threat not only to the patient but also to the whole hospital environment (Heczko and WójkowskaMach, 2009).

This study used a random sampling strategy in HEDs environment and in a control workplaces (offices) not exposed to contact with harmful biological agents. The samples were taken from hospital surfaces (floors, walls, tables) and irregular, hard to access or frequently used surfaces (ventilation grilles, keyboards, medical device buttons, pens etc.) that may pose a risk of possible transfer of pathogenic microorganisms.

Environmental samples for this research were collected in the autumn and winter of 2014. All materials were sampled from areas with normal work system in HEDs in the presence of patients, visitors and medical personnel. Sampling apparatus was placed at height of around $0.8-1.2 \mathrm{~m}$ in a representative location of the examined spaces. The examined areas were varied in relation to the capacity and numbers of beds. All rooms were equipped in gravity ventilation systems. In total, 90 samples were collected in 10 Hospital Emergency Departments, including 20 air samples (HED's rooms and corridors) and 30 imprint samples; the last were taken in order to assess the total number of microorganisms. The remaining 40 samples were collected by swabbing high risk surfaces, e.g. door handles, keyboards, badges, pens. A similar sampling algorithm was adopted in the analysis of microbiological contamination of control workplaces, where a total of 80 samples were collected, 70 samples from surfaces (30 - imprints, 40 - swabs) and 10 air samples. In total, 170 environmental samples were collected from HEDs and offices. The biological material from imprinting samples Count-Tact ${ }^{\oplus} 3 \mathrm{P}^{\mathrm{\tau}}$ Agar-CT3P (bioMérieux, France), together with samples collected using swabs, was inoculated on selective culture media and prepared in accordance with the generally accepted microbiological diagnostic procedures.

Air sampling was carried out with the assistance of a Coriolis Recon apparatus (Bertin, France); this technic collects a large amount of biological particles $(0.5-10.0 \mu \mathrm{m})$ in a liquid sample at a flow rate of $6 \mathrm{~m}^{3}$ (for $10 \mathrm{~min}$ ) and allows preparation of a highly representative sample for further microbiological analysis.

Air samples were filtered through a $0.22 \mu \mathrm{m}$ filter (Merck Millipore, Poland) using the filtering apparatus vacuum pump P504 Millipore (Merck Millipore, Poland). The filter was placed on the surface of Columbia agar medium with 5\% sheep blood (Graso Biotech, Poland), and the culture of the biological material was incubated at $37^{\circ} \mathrm{C}$ for $24 \mathrm{~h}$; the following stages were carried out in accordance with the generally accepted diagnostic scheme. Identification and testing the strains of bacteria for susceptibility to various groups of antibiotics was carried out using an automated system
Vitek 2 Compact (bioMérieux, France) following the manufacturer's instructions. For confirmation of antimicrobial resistance of bacterial isolates the disc diffusion method was used according to actual EUCAST recommendation (www.korld.edu.pl/spec-rekomendacje-eucast.php). Controls for the study were conducted using following reference strains: Escherichia coli ATCC 25922, Enterococcus faecalis ATCC 29212, Staphylococcus aureus ATCC 29213, Pseudomonas aeruginosa ATCC 27853, Klebsiella pneumoniae ATCC 700603, Streptococcus pneumoniae ATCC 49619.

Statistical evaluation of the obtained results by three methods was done by Mann-Whitney test because the analysed data have not passed Shapiro-Wilk normality test (GraphPadPrism, USA). The difference is statistically significant at $\mathrm{P}<0.05$.

Harmful biological agents are a significant problem in occupational medicine and environmental health. Identification and characterization of the agents in the hospital environment makes it possible to conduct a reliable risk assessment of biological hazards to medical emergency staff in HEDs (Kramer et al., 2006). The standards of assessment of the microbiological hygiene status of contact surfaces in medical institutions were suggested by the US Department of Agriculture $\left(<5 \mathrm{cfu} / \mathrm{cm}^{2}\right.$ and $<1 \mathrm{cfu} / \mathrm{cm}^{2}$ for indicator organisms: S. aureus, Clostridium difficile, vancomycin-resistant Enterococcus (VRE), multidrug resistance (MDR) Gramnegative Bacilli, Salmonella spp., E. coli O157) (Dancer, 2004). According to these standards, the status of contact surfaces contamination (floors, walls, tables) in the examined HEDs falls within the permissible norm (Table I). All examined surfaces in HEDs vs. offices, except floors, revealed statistically significant differences. In similar studies concerning the levels of biological contamination of small scale medical equipment e.g. stethoscope (Shiferaw et al., 2013), a significant degree of micro-contamination was revealed (micro-contamination $\geq 20 \mathrm{cfu}$ per membrane; the equivalent of approx. $2 \mathrm{cfu} / \mathrm{cm}^{2}$ ). In the light of the above, the hygiene status of the examined contact surface in HEDs seems to be satisfactory. It may be the result of correct implementation of the Standard Protective Precautions and effective disinfection and decontamination procedures (Dancer, 2004). Microbiological contamination of air in HEDs rooms and corridors was on average at the level of $2.1 \times 10^{1} \mathrm{cfu} / \mathrm{m}^{3}$ and $3.8 \times 10^{1} \mathrm{cfu} / \mathrm{m}^{3}$, respectively. The mean value of air micro-contamination in offices was $1.4 \times 10^{1} \mathrm{cfu} / \mathrm{m}^{3}$ (bacteria) (Table I).

According to the research of the past few decades, micro-contamination of air in hospital rooms varies depending on the sterility class of the examined hospital rooms e.g. from $7.0 \times 10^{1} \mathrm{cfu} / \mathrm{m}^{3}$ for bacteria and fungi as the highest acceptable concentration in 
Table I

Total number of bacteria from tested sites

\begin{tabular}{|c|c|c|c|c|c|c|c|}
\hline \multirow{3}{*}{$\begin{array}{c}\text { Tested } \\
\text { sites }\end{array}$} & \multicolumn{7}{|c|}{ Imprint samples $\left(\mathrm{cfu} / 25 \mathrm{~cm}^{2}\right)$} \\
\hline & \multicolumn{3}{|c|}{ HEDs; $n^{\star}=30$} & \multicolumn{3}{|c|}{ Offices; $\mathrm{n}^{\star}=30$} & \multirow{2}{*}{ P value ${ }^{* *}$} \\
\hline & Mean values \pm SD & Median values & Min.-Max. & Mean values \pm SD & Median values & Min.-Max. & \\
\hline Tables & $8.7 \times 10^{1} \pm 8.4 \times 10^{1}$ & $5.5 \times 10^{1}$ & $18-260$ & $2.6 \times 10^{1} \pm 2.9 \times 10^{1}$ & $1.3 \times 10^{1}$ & $2-90$ & 0.0147 \\
\hline Floors & $1.3 \times 10^{2} \pm 1.0 \times 10^{2}$ & $1.1 \times 10^{2}$ & $16-300$ & $8.4 \times 10^{1} \pm 9.8 \times 10^{1}$ & $4.4 \times 10^{1}$ & $4-300$ & 0.1502 \\
\hline Walls & $3.5 \times 10^{1} \pm 3.4 \times 10^{1}$ & $1.9 \times 10^{1}$ & $6-100$ & $1.0 \times 10^{1} \pm 7.5 \times 10^{0}$ & $1.0 \times 10^{1}$ & $0-20$ & 0.0310 \\
\hline Total & $8.6 \times 10^{1} \pm 8.6 \times 10^{1}$ & $6.2 \times 10^{1}$ & $6-300$ & $4.0 \times 10^{1} \pm 6.6 \times 10^{1}$ & $1.6 \times 10^{1}$ & $0-300$ & 0.0009 \\
\hline \multicolumn{8}{|c|}{ Air samples $\left(\mathrm{cfu} / \mathrm{m}^{3}\right)$} \\
\hline & \multicolumn{3}{|c|}{ HEDs; $n^{\star}=20$} & \multicolumn{3}{|c|}{ Offices; $\mathrm{n}^{\star}=10$} & \\
\hline Air & $2.8 \times 10^{1} \pm 1.9 \times 10^{1}$ & $2.8 \times 10^{1}$ & $2-70$ & $1.3 \times 10^{1} \pm 1.2 \times 10^{1}$ & $8.0 \times 10^{0}$ & $3-42$ & 0.0365 \\
\hline
\end{tabular}

${ }^{\star} \mathrm{n}=$ number of samples ${ }^{* *}$ - calculated with Mann-Whitney test

a neurosurgical wards to $7.0 \times 10^{2} \mathrm{cfu} / \mathrm{m}^{3}$ as the highest acceptable concentration in treatment rooms (Górny, 2004). Other examples of microbiological assessment analyses are presented by Rubino (1995), according to whom, the level $0-2.3 \times 10^{1} \mathrm{cfu} / \mathrm{m}^{3}$ is pronounced as very good and the value $>3.75 \times 10^{2} \mathrm{cfu} / \mathrm{m}^{3}$ marks a highly unsatisfactory level of microbiological contamination (Charkowska, 2003).

According to new surveys the trends of microbiological air contamination are for an improvement of quantitative and qualitative status of bio-aerosols of the hospital environments (Ekhaise et al., 2008; Hoseinzadeh et al., 2013; Mirzaei et al., 2014).

Microbiological air quality is frequently monitored in sterile hospital rooms (where the risk of infection is highest) however, there is little data about air microcontamination of hospital corridors. Some research was presented by Park et al. (2013), who registered the air microbiological contamination in hospital corridors at the level $7.2 \times 10^{2} \mathrm{cfu} / \mathrm{m}^{3}$ for the bacteria. The values found here are much higher than the ones registered in "clean rooms" (e.g. operation rooms or haematology, pulmonology, obstetrics and gynaecology wards). The hospital wards with the highest level of sterility such as surgical and transplant units present the microbiological contamination in the range from $0.01-1 \times 10^{1} \mathrm{cfu} / \mathrm{m}^{3}$ (Park et al., 2013).

However, in our research, both HEDs rooms and corridors represent the microbiological contamination at the level of $2.7 \times 10^{1} \mathrm{cfu} / \mathrm{m}^{3}$, which places them within the limits of accepted standards (Gołofit-Szymczak et al., 2013). Also in the research conducted by Augustowska and Dutkiewicz (2006) concentrations of bacteria in the air assumed values from 1.0 to $9.6 \times 10^{1} \mathrm{cfu} / \mathrm{m}^{3}$.

Relatively low concentrations of microorganisms detected in the hospital environment (contact surfaces and air) may result from improved levels of hygiene in hospitals due to infrastructure development (air conditioning and highly efficient HEPA filters) and implementation of modern and highly effective sanitary procedures. Another preventive measure reducing microbiological contamination in the hospital environment is the implementation of hospital infection control teams. This study, carried out in the winter, achieved quantitative results similar to the values observed by other researchers who conducted their tests in the same season (NSI, 2009; 2010; 2011).

In assessing the microbiological quality of samples, this research found mainly non-fermentative Gramnegative Bacilli (NFGNB) and Stenotrophomonas maltophilia, naturally resistant to many broad-spectrum antibiotics (e.g. $\beta$-lactams including all carbapenems) and coagulase-negative Staphylococci (CoNS) with constitutive macrolide-lincosamide-streptogramin $\mathrm{B}\left(\mathrm{cMLS}_{\mathrm{B}}\right)$ and macrolide-streptogramin $\mathrm{B}\left(\mathrm{MS}_{\mathrm{B}}\right)$ phenotypes (Table II).

These bacteria may constitute a considerable risk of HAIs due to their resistance to a large number of antibiotics and antimicrobial therefore cause treatment problems; the bacteria may be classified as potentially pathogenic agents. In the examined contact and swab samples collected from HEDs, NFGB were prevalent. In air samples, besides the mentioned NFGNB Acinetobacter spp. and S. maltophilia (mainly isolated from HEDs corridors) large numbers of CoNS with constitutive $\mathrm{MLS}_{\mathrm{B}}$ (especially in HEDs rooms) were found. In the tested air samples from HED corridors mainly NFGNB were found; in HEDs rooms CoNS with constitutive $\mathrm{MLS}_{\mathrm{B}}$ were isolated. In hospital offices contact and swab samples contained mainly CoNS; in the air samples no pathogens were detected (Table II). Comparison of the proportional presence of pathogenic bacteria isolated by three different methods revealed $9.8 \%$ of pathogens detected by imprint method and 10.5\% of pathogens by swabbing method; and in relation to air sampling $17.6 \%$ and $22 \%$ for HEDs corridors and rooms, respectively. In offices pathogenic bacteria reached the level of $6.5 \%$ and $14.7 \%$ for imprint method 
Table II

The percentage of potential pathogens in relation to the number of all isolates

\begin{tabular}{|c|c|c|c|c|c|}
\hline \multirow[t]{2}{*}{ Places } & \multirow[t]{2}{*}{ Samples } & \multicolumn{2}{|c|}{$\begin{array}{c}\text { NFGNB } \\
\text { (non-fermentative } \\
\text { Gram-negative Bacilli) }\end{array}$} & \multicolumn{2}{|c|}{$\begin{array}{c}\text { CoNS } \\
\text { (coagulase-negative } \\
\text { Staphylococci) }\end{array}$} \\
\hline & & Species & $\%$ & Species & $\%$ \\
\hline \multirow[t]{12}{*}{ HEDs } & \multirow[t]{3}{*}{ Imprints $(\mathrm{n}=30)$} & ${ }^{\star}$ B. cepacia & 2.0 & \multirow[t]{3}{*}{${ }^{I}$ S. saprophyticus } & \multirow[t]{3}{*}{3.9} \\
\hline & & S. maltophilia & 2.0 & & \\
\hline & & A. lwoffii & 2.0 & & \\
\hline & \multirow[t]{3}{*}{ Swabs $(\mathrm{n}=40)$} & A. lwoffii & 2.8 & \multirow[t]{3}{*}{ Not detected } & \\
\hline & & A. haemolyticus & 2.8 & & \\
\hline & & A. radioresistens & 2.8 & & \\
\hline & \multirow{3}{*}{$\begin{array}{l}\text { Air }(n=10) \\
\text { Corridor }\end{array}$} & S. maltophilia & 10.0 & \multirow[t]{3}{*}{ Not detected } & \\
\hline & & ${ }^{* *}$ A. baumannii cplx & 5.0 & & \\
\hline & & A. lwoffii & 5.0 & & \\
\hline & \multirow{3}{*}{$\begin{array}{l}\text { Air }(n=10) \\
\text { Rooms }\end{array}$} & \multirow[t]{3}{*}{ Not detected } & & ${ }^{2} S$. haemolytcius & 2.6 \\
\hline & & & & ${ }^{2}$ S. hominis & 2.6 \\
\hline & & & & ${ }^{3}$ S. lentus & 2.6 \\
\hline \multirow[t]{6}{*}{ Offices } & \multirow[t]{3}{*}{ Imprints $(\mathrm{n}=30)$} & A. lwoffii & 11.4 & S. hominis & 2.9 \\
\hline & & \multirow[t]{2}{*}{ A. baumannii } & \multirow[t]{2}{*}{2.0} & S. haemolyticus & 2.9 \\
\hline & & & & S. warnerii & 2.9 \\
\hline & \multirow[t]{2}{*}{ Swabs $(\mathrm{n}=30)$} & \multirow[t]{2}{*}{ Not detected } & & S. warnerii & 6.6 \\
\hline & & & & S. hominis & 6.6 \\
\hline & $\operatorname{Air}(n=10)$ & Not detected & & Not detected & \\
\hline
\end{tabular}

* isolate with ESBL resistance phenotype (alert-pathogen), ${ }^{* *}$ multidrug resistance alert-pathogen,

$\mathrm{n}$ - number of samples, ${ }^{1} 1$ isolate with $\mathrm{MS}_{\mathrm{B}}$ and 1 isolate with $\mathrm{CMLS}_{\mathrm{B}}$ and methicilin-resistant

coagulaso-negative Staphylococci MRCNS, ${ }^{2}$ isolate with $\mathrm{cMLS}_{\mathrm{B}},{ }^{3}$ isolate with MRCNS and cMLS

and swabbing, respectively. In the air samples pathogenic microorganisms were not detected.

Widespread usage of antibiotics, both in hospitals and ambulatory treatments, has led to the selection of pathogens with varied phenotypes of antimicrobial resistance i.e. alert-pathogens. Among the pathogens isolated from contact and air samples collected in HEDs, this study detected two multidrug-resistant Acinetobacter baumannii (MRAB) and producing extended sepctrum of $\beta$-lactamases Burkholderia cepacia (ESBL+) (Table II). According to the Ordinance of the Polish Ministry of Health, December 23 ${ }^{\text {rd }}, 2011$ (List of alert pathogens, Attachment 1) these belong to alert pathogens (isap.sejm.gov.pl).

Literature concerning microbiological quality assessment discusses mainly research conducted in wards requiring long-term hospitalising e.g. intensive care, internal, haematology, urology, ophthalmology and surgical wards (Kępa et al., 2012; Nourmoradi et al., 2012; Paluchowska et al., 2012a; 2012b; Guzek et al., 2013; Hoseinzadeh et al., 2013; Seweryn et al., 2014). In this study, the bacteriological quality analysis of isolates from hospital environment (HEDs) correlates with the profiles of potentially pathogenic species determined by other researchers in similar tests. For example, in other studies the main bacterial isolates responsible for microbiological contamination of contact surfaces in hospitals (floors, medical tables, couches, washbasins) were methicillinresistant S. aureus (MRSA), VRE, Clostridium difficile, multidrug-resistant Acinetobacter spp., Pseudomonas spp., Enterococcus spp., and additionally Enterobacteriaceae ESBL+ (E. coli, Enterobacter spp., Salmonella spp. and Klebsiella spp.) (Kramer et al., 2006; Garcia-Cruz et al., 2012; Weber et al., 2013; Seweryn et al., 2014).

According to Paluchowska et al. (2012b) the largest proportion of HAIs caused by alert-pathogens is registered in intensive care wards, burns units, internal, haematological and surgical wards. The pathogens isolated most often were multi-drug resistant, NFGNB (mainly A.baumannii and P.aeruginosa) which are recognised as the most problematic to control and eradicate (Paluchowska et al., 2012b). CoNS and Enterococcus spp. are the key factors in HAIs and they are mostly isolated form surgical, haematological and oncology wards (Guzek et al., 2013; Nourmoradi et al., 2012; Hoseinzadeh et al., 2013). Additionally MRCNS and NFGNB isolated from urology wards may constitute sources of infection (Kępa et al., 2012).

The results quoted above show that the diversity of microorganisms detected in this study is comparable 
with the standard trends. In quality testing of control samples alert-pathogens were not detected; however, potentially pathogenic strains (mainly CoNS) were found. The relatively low level of contamination by bacteria in HEDs may attest to the effectiveness of implementing the standard protective precautions in the examined hospitals. In quality assessment of HEDs the main bacterial strains found were NFGNB and CoNS; the presence of the bacteria may result from person to person transmission or introduction of pathogens from outside the hospital.

\section{Acknowledgements}

This article was funded by the project number II.P.19 (contract number 42/2014/PW-PB) named "Identification of biological hazards in rescue operations and their impact on the competence of the immune system, in the perspective of health consequences" and carried out under the program "Improving safety and working conditions" conducted by Central Institute for Labour Protection - National Research Institute.

\section{Literature}

Augustowska M. and J. Dutkiewicz. 2006. Variability of airborne microflora in a hospital ward within a period of one year. Ann. Agric. Environ. Med. 13: 99-106.

Charkowska A. 2003. Contamination in air conditioner and their method of removing them (in Polish). Ippu Masta, pp. 1-60.

Dancer S.J. 2004. How do we assess hospital cleaning? A proposal for microbiological standards for surface hygiene in hospitals. J. Hosp. Infect. 56: 10-15.

European Committee on Antimicrobial Susceptibility Testing (EUCAST). Breakpoint tables for interpretation of MICs and zone diameters, Version 5.0 valid from 2015-01-01. Available from http:// www.eucast.org/clinical_breakpoints.

Ekhaise F.O., O.U. Ighosewe and O.D. Ajakpovi. 2008. Hospital indoor airborne microflora in private and government owned hospitals in Benin City Nigeria. World J. Med. Sci. 3: 19-23.

Fiedotow M. and A. Denys. 2006. Selected aspects of nosocomial infections (in Polish). Pol. Merkuriusz Lek. 21: 484-485.

Garcia-Cruz C.P., M.J.N. Aguilar and O.E Arroyo-Helguera. 2012 Fungal and bacterial contamination on indoor surfaces of a hospital in Mexico. Jundishapur J. Microbiol. 5: 460-464.

Gołofit-Szymczak M., A. Ławniczek-Wałczyk and R. Górny. 2013 Quantitative and qualitative methods of assessing harmful biologica agents in the working environment (in Polish). Pod. Met. Oceny Srod. Pracy. 2: 5-17.

Górny R.L. 2004. Biohazards: standards, guidelines, and proposals for threshold limit values (in Polish). Pod. i Met. Oceny Środ. Pracy 3: 17-39. Guzek A., K. Korzeniewski, A. Nitsch-Osuch, Z. Rybicki and E. Prokop. 2013. In vitro susceptibility of Staphylococci and Enterococci to vancomycin and teicoplanin. Adv. Exp. Med. Biol. 788 $125-132$.
Heczko P.B. and J. Wójkowska-Mach. 2009. Nosocomial infections (in Polish), $1^{\text {st }}$ ed. p. 61. PZWL, Warszawa.

Hoseinzadeh E., M.R. Samarghandie, S.A. Ghiasian, M.Y. Alikhani and G. Roshanaie. 2013. Evaluation of bioaerosols in five educational hospitals wards air in Hamedan, during 2011-2012. Jundishapur J. Microbiol. 6(6): e10704.

ISAP. 2011. Ordinance of Polish Ministry of Health, December $23^{\text {rd }}$. http://www.isap.sejm.gov.pl, 2015.11.30.

Kępa M., R.D. Wojtyczka, D. Idzik, M. Mrówka, K. Jasik and J. Pacha. 2012. Antimicrobial susceptibility of bacterial strains isolated at Urology Ward environment (in Polish). Ann. Acad. Med. Siles. 66: 7-15.

Kramer A., I. Schwebke and G. Kampf. 2006. How long do nosocomial pathogens persist on inanimate surfaces?. BMC Infect. Dis. 6: 130 .

Maszkiewicz W. 2007. Nosocomial infections in neonates (in Polish). Zdr. Publ. 117: 260-263.

Mirzaei R., E. Shahriary, M.I. Qureshi, A. Rakhshkhorshid, A. Khammary and M. Mohammadi. 2014. Quantitative and qualitative evaluation of bio-aerosols in surgery rooms and emergency department of an educational hospital. Jundishapur J. Microbiol. 7(10): e11688.

National Sanitary Inspectorate (NSI). 2009. Country Sanitary Conditions Report. http://www.gis.gov.pl, 2015.11.30.

National Sanitary Inspectorate (NSI). 2010. Country Sanitary Conditions Report. http://www.gis.gov.pl, 2015.11.30.

National Sanitary Inspectorate (NSI). 2011. Country Sanitary Conditions Report. http://www.gis.gov.pl, 2015.11.30.

Nourmoradi H., M.M. Amin, M. Hatamzadeh and M. Nikaeen. 2012. Evaluation of bio-aerosols concentration in the different wards of three educational hospitals in Iran. Int. J. Env. Health Eng. 1: 47. Paluchowska P., M. Skałkowska, A. Szelak and A. Budak. 2012a. Occurrence of alert pathogens in hospital environment. Part I. ESBL-producing Enterobacteriaceae strains (in Polish). Med. Dośw. Mikrobiol. 64: 35-43.

Paluchowska P., M. Skałkowska, A. Szelak and A. Budak. 2012b. Occurrence of alert pathogens in hospital environment. Part II. Multidrug-resistance non-fermenting Bacilli (in Polish). Med. Dośw. Mikrobiol. 64: 45-53.

Park D.-U., J.-K. Yeom, W.J. Lee and K. Lee. 2013. Assessment of the levels of airborne bacteria, Gram-negative bacteria, and fungi in hospital lobbies. Int. J. Environ. Res. Public Health. 10: 541-555. Rubino F.M., S. Basilico, G. Bernazzani, G. Bocchi, A. Colombi, M. Margonari, and E. Occhipinti. 1995. Air quality monitoring in Grattacielo Pirelli of Milan, a large, conditionated office building. Proc. Healthy Build. 95(3): 1389-1394.

Seweryn M., K. Bandoła, M.M. Bała, S. Sroka, M. Koperny and M. Wszołek. 2014. Alert pathogens detected among patients hospitalized at hospitals of the Lesser Poland Voivodeship in years 2010-2012 (in Polish). Przegl. Epidemiol. 68: 549-553.

Shiferaw T., G. Beyene, T. Kassa and T. Sewunet. 2013. Bacterial contamination, bacterial profile and antimicrobial susceptibility pattern of isolates from stethoscopes at Jimma University Specialized Hospital. Ann. Clin. Microbiol. Antimicrobiol. 12: 39.

Weber D.J., D. Anderson and W.A. Rutala. 2013. The role of the surface environment in healthcare - associated infections. Curr. Opin. Infect. Dis. 26: 338-344. 
